\title{
THE ANNALS OF IOWA,
}

BY THE

\section{STATE HISTORICAL SOCIETY,}

IOWA CITY, JANUARY, 1866.

\section{NUMIBER XIII.}

\section{HISTORY OF DAVIS COUNTY, IOWA.}

CHAPTER III.

[Continued from page 447.]

OUR NAME.

If our county had been called Smith, there would have been no difficulty in solving the oft repeated question, "For whom was your county named?" For we conceive there is not a single individual, either in Europe or America, making the least claim to respectability or intelligence who is not acquainted with Smith! But if any one should be so obtuse, or so devoid of common understanding as to ask, "for what Smith ?" we feel fully justified in making the assertion that there is no man, woman or child in all the "Hairy Nation"-including the brushiest part of "Hackelbarney" - so stupid but that they would at once answer, "for John Smith, of course," for all will agree with me, that John is one of the most noted of that most numerous and respectable family! But, unfortunately for this generation and the generations that are to follow in the footsteps of this, the senatorial council and representative branches of the Legislative Assembly of the Territory of Iowa in 1844 , thoughit proper to give us some other name. It 
becomes our duty in this connection to record that the General Assembly aforesaid, forgetting that some one or more of the citizens of Iowa, in after time, might possibly be pleased to know in honor of whom our county received its name, and entirely overlooking the Smiths and ignoring the claims of all that highly respectable family, and particularly the claims of the John Smiths, by solemn act of the two branches, fastened upon us, and may be, upon all future generations, the name of DAvis!

Now we come again to the question, "For whom was your county named?" In the first place we have been informed that it was named for Joe Daviess, but we have invariably contra. dicted it, from the fact that Joe in spelling his name used an $e$ and two $s^{\prime} s$, while our county has no $e$, and but one $s$ in it; which, we think, settles that point. In the second place we have heard that it was named for John Davis-honest Johnof Massachusetts. This we also contradict, and for this reason: It is as plain as the nose on a man's face, if even one member of the General Assembly of the Territory had thought of John Davis, nothing could be more certain than that other popular individual-John Smith-would have popped into his brain, and this would have been Smith county, and not Davis county. This we think settles the question adverse to the claims of honest John of the old Bay State. In the third place, some have suggested that Richard W. Davis-known all over the "Hairy Nation" and along the Chariton river as far up as Pilkey's Mills-is entitled to the honor; but uncle Dickey, as he is now familiarly called, declines it, and for my part, I think he is in the right, and in support of my position I offer this argument: No one will doubt, we feel assured, that if the member who drew up the bill defining the boundaries of our county had thought of Richard Davis, that other distinguished Richard who slew on the bloody battlefield of the Thames the Great War-chief, would have penetrated his cranium, and that our name would have been either Dick or Jolunson. Here, then, we see that this Davis cannot 
have the honor, even if he desired it. In the fourth place, we have heard the claims of Jeff, the most notorious, at this time, of all the Davis family, canvassed. At this time, however, all agree that he is not entitled to the honor: and in order to show that he is not the man for whom our county was named, some of the most logical arguments ever produced in the vicinity of Fox River or Carter's Creek, have been brought to bear, and among which I might name, first: That the solemn and august body legislating for the Territory of Iowa in the year of grace, 1844,-far-seeing as said body was-would not have named a county for a traitor! And secondly: That if that body had acted so indiscreetly, our last General Assembly - being composed of members both wise and otherwise - would have promptly changed the name, and would have called it either Smith or Brown! These and other arguments of a less logical character, have been made against any claims Jeff may have set up to the honor, and I think they clearly demonstrate that he is not the man!

After canvassing the claims of many of the Davises, including A. J. Davis, who makes whisky near Iowaville, and our fellow-townsman, John R. Davis, who invented and patented a corn cultivator, I addressed a note to Dr. John D. Elbert, of Van Buren County, and from his reply make the following extract:

"Mr. James Jenkins and myself were members of the territorial council at the time Davis County was organized. The name was adopted at the suggestion of some of us Kentuckians, who wanted to honor a distinguished politician and Congressman by the name of Garrett Davis of Lexington, (Ky.,) district, $* * * *$ who had endeared himself to the west, and was thought worthy of the honor."

From Capt. J. H. Bonney of Keosanqua, (who was at the Capital at the time our county received its name,) and from Hon. James M. Wray, Hon. David Ferguson and others of our county, I learn that after the close of the "territorial war" between the citizens of the State of Missouri and the Territo- 
ry of Iowa, those persons in this Territory who were ordered to march to the seat of war by the Territorial Governor and United States Marshal, made application to Congress for compensation for their time and money spent in the defense of their homes. Their application was referred to the committee on claims, of which Mr. Davis was chairman. Regarding their claims just, Mr. Davis reported to the House a bill appropriating a sum sufficient to compensate them, and otherwise took an active part (as also did Gov. Wise of Va.,) in favor of making the appropriation. During the pendency of Mr. Davis' bill in the House, the Territorial Legislature of Iowa was in session, and passed an act defining the boundaries of our county, and named it $D_{\Lambda V I s}$. So it turns out that our county was named for Hon. Garretr Davis, at present, one of the United States Senators from Kentucky. Thus, upon good authority, it is now settled that it was not named for Joe, whom the Indians killed in battle, nor for honest John of Massachusetts, nor uncle Dickey who traps "minks" on the Chariton, nor for Jeff who runs a bogus machine at Richmond, nor A. J. who makes whisky at Iowaville, nor John P. who invented the corn cultivator!

And I must confess, since I have ascertained to a certainty for whom it was named, that I am truly glad that it was not called Smith; this I say, however, without intending any disparagement to the Smith family, or in any way endorsing the general course of Senator Davis. But for this reason am I glad: If, in their wisdom, a majority of the members of the General Assembly of the Territury of Iowa in 1844, had solemnly enacted that our county should be called Smith, in digging after the origin of the name, I might have traced it back to Delazon, the lost minister to South America, whom Senator Benton compared to the man who went into "Sims" Hole," or to Extra Billy of Virginia, neither of whom would have reflected half the lustre upon the bright escutcheon of a great county like ours that John would! 
POLITICAL DIVISION,

At the July session of the board of County Commissioners, in the year 1844, the county was divided into seven election precincts; and Appanoose county at that time attached to Davis for election purposes was divided into two precincts.They were as follows: Number one at the home of William Williamson, number two at the home of Willis Faught, number three at the home of W. W. Rankin, number four at the home of Noble C. Barron, number five at the home of S. Atleberry, number six at the home of Reuben R. Reeves, number seven at the house of J. W. Picket. Those of Appanoose Co., and at that time under the jurisdiction of our county court, were as follows: Number eight at the house of William Mooney, and number nine at the house of Richard W. Davis.

Thus our county was divided and remained until the 7 th day of January, 1846, when the County Commissioners' Court proceeded to divide our county into civil townships as follows:

Townships. - "Ordered that Congressional township seventy north, range twelve west, be organized and called Salt Creek township." Township seventy north, range thirteen west, be called Lick Creek; township seventy north, range fourteen west, be called Soap Creek; township seventy north, range fifteen west be called Marion; township sixty-nine north, range fifteen west, be called Fox River; township sixty-nine north, rang@ fourteen west, be called Bloomfield; township sixty-nine north, range thirteen west, be called Perry; township sixty-nine north, and one mile off of the north side of township sixty-eight north, range twelve west, be called Union; township sixty-eight (except one mile off of the north side,) and all that part of township sixty-seven north, range twelve west, within our county, be called Prairie; township sixty-eight and fractional township sixty-seven north, range thirteen west, be called Grove; township sixty-seven north, range fourteen west, be called Wycondah; and that township sixty-eight and fractional township sixty-seven north, range fifteen west, be called Fabius. 
The places of holding elections in the several townships were fixed as follows: In Salt Creek, at the house of Richard Cave; in Lick Creek at that of Robert Merchant; in Soap Creek at that of A. H. Putman; in Marion at that of Alexander Downing; in Fox River at that of Robert Jones ; in Bloomfield at the Court House ; in Perry at the house of Samuel Evans, Sr.; in Union at that of Richard Goddard; in Prairie at that of Samuel Monday ; in Grove at that of A. Conoway; in Wycondah at that of James W. Paris, and in Fabius at that of Elias Veatch.

Thus our county remained divided into political townships for some time, but as the county settled up, in order to accommodate the wants of our citizens, the township of Prairie was divided by a line running east and west, and the south half of it called Roscoe; parts of the townships of Perry and Grove were attached to Bloomfield, and the north west part of Bloomfield township was stricken off, and organized as Drakeville.

Salt Creek township was first settled by James H. Jordan, Van Caldwell, Jesse Testament, Job Carter, William Higgins, Henry Smith, John Tollman, Peter Woods, a Mr. Wainscate, and others in 1837-8. It was in this township that the first mill was built, which was put up by the United States government in 1837. In 1838, this Mill was carried away by a flood, but was rebuilt by the government in 1839 . The trading post of Mr. Jordan and this Mill had attracted quite a settlement in this township, and the pioneers had begun to improve their "claims," and had a very flattering prospect of abundant crops of wheat, corn, potatoes, \&c., and about the time wheat was ripening for the sickle, the United States Dragoons came along and burnt their cabins and fences and destroyed their crops. This was in 1840, and within a few days from that time the government mill took fire and was consumed. How this mill took fire is not known, but it was not fired, by accident, from the fact that several settlers had bags of grain at the mill which were carried out of the way of the fire, where they were found and reclaimed the next day after the 
destruction. Mr. John Tollman was the principal contractor with the United States Government for building this mill, and Mr. Peter Woods became his partner in the contract, for which they received three thousand dollars. The same or next year Mr. Jordan rebuilt the mill, it being on his own "claim," and being one of the best mill sites in our county. In 185 this township contained a population of 818 , of which 159 were voters and 149 subject to military duty. There were 152 families and 121 land owners. Their occupations were as follows : Farmers 114, Laborers 33, Mechanics 19, Teachers 2, and Physician 1. In 1863 the population was 784, of which 149 were voters and 97 subject to military duty. The number between the ages of five and twenty-one 256. This is a township of fine lands, timber, stone and stone coal; and is well watered by the Des Moines river, Soap creek, Salt creek and other smaller streams. There are several religious organizations and meeting houses in the township, as well as School houses and Mills. At this time there is no post office in Salt creek-the only one ever established having been discontinued last year; and by the way, while speaking of that post office, it would not be amiss to mention its establishment and operation during the first quarter, which I remember about as follows :

Post OfFice Returas.-About the beginning of the administration of President Taylor, Salt Creek post office was established, and F. C. Humble, Esq., our first sheriff, received the appointment of Post Master. Having entered into bonds and taken the oath required by law, Mr. Humble entered upon the duties of his office with ostentation, and discharged the onerous functions of the same promptly, with neatness and dispatch, to the end of the first quarter. On the first of July, he turned to the laws and instructions of the post office department, which he kept snugly folded and stuck in a crack of his cabin near the jamb of the chimney, and carefully read the chapter relating to quarterly returns. He failed to fully comprehend the instructions, but on counting the money on hand, 
he found that the gross receipts of the office had been ninetyfive cents, all in coin-current coin of the realm. He knew not what part of the sum was rightfully his due, and being determined that no charge should ever be made against him of having taken illegal fees or kept government money, he deliberately collected together all the post-bills recived at, and the transcript of letters sent from, his office up to date, and placing a five franc piece in the centre, bundled the whole in one package, tied it with a buck-skin string, and addressed it "To Mr. Z. Taylor, President of the United States of America!" In a private note to the President he stated that ninety-five cents was all the money he had collected, and inasmuch as he had accepted the office more for the accommodation of his neighbors than for the fees and emoluments, the President might keep the whole amount! By due course of mail the package was received at Washington, but was returned to $\mathrm{Mr}$. Humble for correction. Without delay he repaired to the County seat, bringing with him all the books, papers and money belonging to the office, and at his request, the writer of this sketch made his returns and wrote out his resignation, all of which twas signed by him and accepted by the department.

Lick Creek Township was first settled by D. P. Crumrine, Josiah Stark, Delany and Elijah Sweeny, Wm. Garrettson, S. C. Allen, D. Niles, Ransom Wooden, Robert Merchant and others. The north part of this township is principally timbered land, and the first settlers here were generally from Indiana and other timbered sections of the country, and settled therefore in the timber. It was in this and the other northern townships of our county that deer and other game were so numerous in the first settlement of the county; and hence most of our oldest and most successful hunters reside in this or adjoining townships. Lick creek can boast of two villages -Floris and Chequest-as well as several houses of public worship. It also lias its proportion of school houses, steam mills, \&c. I have been unable to procure the statistics of this township only for 1856 and 1863 . In the former year the 
population was 761 of whom 142 were voters. The amount realized for sale of cattle was $\$ 9,088$. Her population in 1863 was 1,071 of whom 190 were voters and 151 subject to military duty.

The District Court Honxed.-At a very early day in the settlement of this township, Mr. Ransom Wooden became involved in law as to the ownership of a horse, and by order of Justice Merchant, Mr. Josiah Stark, then a constable, was ordered to deprive Mr. Wooden of the possession of the animal. Mr. Stark armed with the proper writ undertook to seize the horse but Mr. Wooden made resistance, and the constable was therefore unable to discharge his duty as the law directed. At the sitting of the District Court, the grand jury found and presented a "true bill" against Mr. Wooden for resisting the officer while attempting to serve legal process. He was duly arrested by the sheriff, and entered into bond in the penal sum of three hundred dollars for his appearance at the next term of the court to answer to the charge. $\mathrm{Mr}$. Wooden had but little acquaintance with District Courts, and did not therefore, care to come in contact with that institution-hence, when the court sat, he did not appear, and the bond was forfeited and a judgment entered against his sureties. They employed counsel who advised them to find Mr. Wooden, bring him into court and then the default could be set aside. Immeciately one of the sureties was dispatched to Burlington whither Mr. Wooden had gone, who brought him to Bloomfield. Here a consultation was had with the attorney who felt pretty certain that upon the trial of the cause Mr. Wooden would be found guilty. Sharp practice was therefore resorted to; Mr. Wooden was wrapped up in blankets and quilt, with handkerchiefs wound about his face and neck, in which condition he appeared at the door of the court room. The attorney for the assurities was on the look-out, and as soon as Mr. Wooden appeared at the door the attorney addressed the court and stated that Mr. Wooden whose bond had been forfeited had now appeared to have the default set aside, and 
that as he, Mr. Wooden, was just breaking out with the small-pox, he hoped the court would act upon the case at once. Judge Mason started in his seat at the word "small-pox," and as quick as thought enquired "With what?" "Small-pox," answered the attorney, at the same time calling the attention of the court to him as he stood at the door. The judge seeing him thus bundled up, sprung to his feet, waiving his hand in quick succession, exclaimed: "Away with him! away with him !" Mr. Wooden passed from the room, mounted his horse and left the county; the court set aside the default, and dismissed the case, and thus Mr. Wooden was clear, and the sureties released from further liability.

SoAp Creek Township, was first settled by Elijah Putman, Jesse C. Blankenship, Abram Weaver, W. W. Rankin, David Shoey, Joel and Jesse Harbor, Charles M. Jenning, Calvin Taylor, Thompson R. Crosswait, Patrick Dawson, William M. Morris, Evan C. Evans, and some others. No settlement was made in this township, I believe, until 1843, when the white man was allowed to settle any part of the county, although many of the first settlers had been here before then and selected claims. The first elections in this part of the county were held at the house of Mr. Rankin, who was one of our first justices. Mr. Blankenship, who still owns and occupies the same place he first settled in this county, was elected one of the delegates to the first Constitutional Convention of Iowa, in 1844, and has ever since been a prominent and leading politician in his township. This township has always contained an energetic and enterprising population, intelligent and thrifty farmers, whose broad fields, well appointed barns and numerous orchards, all attest their wisdom aud industry. It appears, however, that near the north-west corner of this township -in the brush - there was, at an early day, some sort of settlement, which the better class of settlers soon disposed of when once discovered.

Horse Thieves Cacght.-From one of the party I learn that in the autumn of 1842 , Joseph V. Evans, Fleming Mize 
and twenty-nine others, left their homes near Troy, in search of some horses which they supposed had been stolen. As we learn from one of the party, they " armed themselves with rifles, shot-guns, pistols and bowie-knives, and set out with a determination to bring to justice the offender, if he should be found." Suspicion rested on one William Wooden and one Holcomb, then residing in Missouri. The party visited the house of Wooden, but he was not there; they learned, however, from some of his neighbors, that he, and some four or five others, had started for Iowa that morning. Taking their trail, the pursuing party followed them in the direction of Ottumwa, along an Indian trail, wbich passed through the present town of Bloomfield, until within three or four miles of this place, they came to the cabin of William T. Johnson. It was very opportunely too, that they did, for the little stock of bread and meat they had started from home with, was about exhausted, and the party were weary and hungry. He was illy prepared to accommodate, entertain and feed thirty-one men, but with the generosity of a tras squatier, he made the party as comfortable as was in his power, while their horses grazed on the prairie, and Mrs. Johnson prepared a repast of corn bread, bacon and wheat coffee. It was not every squatter's larder that at that time could have done thus much toward the relief of so many hungry stomachs. The guests being ready to proceed on their journey, proffered to pay for their accommodations, but Mr. Johnson refused to receive one cent. This is only one of the many instances of a similar kind that might be named, in contrast with the selfishness of the present more wealthy and aristocratic population of our county. The party separated at Mr. Johnson's, some going one way, some another. Evans, Mize and five others went toward the north-east corner of the county, and when on Soap Creek, by the light of the moon, discovered in a deep hollow a cabin, near which was a wagon and horses. Not knowing who were at the cabin, or for what purpose, the party determined to ride up to the cabin, and assume to be dragoons. Mr. Mize act- 
ing as captain, the seven advanced to the cabin, and in the name of the United States, ordered the occupants of the cabin to surrender. The inmates proved to be Wooden and Holcomb, (the very men they were looking for,) and before they discovered that our party were not dragoons, their arms were taken from them, and they were prisoners in the hands of Captain Mize and his men. The captain immediately started for the settlement with his prisoners-having first formed them in the Indian trail-Indian fashion. Placing first a man on guard in front, then a prisoner, then a guard, and so on-two guards bringing up the rear. The orders of Capt. Mize were to shoot the first man that left the trail.

"Our prisoners," says one of the party, "rode with steady rein, in order to hold their steeds to the track. We traveled all night, and reached the settlements next day in the afternoon." The prisoners were carried into Van Buren County before Justice Richardson, who set them at liberty on account of some informality in the proceedings. But one of the party, whose word we have no desire to question, says the reason the justice gave for discharging the prisoners was, that "they were not arrested" in the county of Van Buren, Territory of Iowa, nor in the "United States!" The next day the owner of the missing horses, with some others, repaired to the place where Wooden and Holcomb had been arrested, and not far from the cabin found the horses grazing on the prairie-being spancelled to prevent them from straying away. Near this cabin was also found quite an improvement, for the times, with corn, pumpkins, watermelons, \&c., growing.

The population of this township in 1863 , was 938 , voters 181, militia, 153 : between the ages of five and twenty-one, 390. This township contains no villages, but at one time there was a post-office within its borders called Harbour, which was discontinued about a year ago. I will relate a little matter connected with the office:

P. M. Wants Two Mrils.-Soon after the election of Gen. Pierce to the Presidency, Charles Wesley Roland who kept a 
little store on his farm in Soap Creek Township, petitioned the Department to establish a post-office at his store. Chas. Wesley was one of the most parsimonious men in the country, but being possessed of a considerable property, and being a new convert to democracy, his efforts were seconded by the leading men of that party. The office was established and he received the appointment of post-master. In course of time it became necessary for him to make return of his doings, and he gathered up his papers and came to Bloomfield. He called at the office of Horn \& Wearer, and requested me to make his returns for him. I did so, and when finished, as I supposed, it was suggested that the returns were ready and only awaited his signature to complete them. Mr. Roland looked over the transcripts and account current with much care, and turning to me said : "Look here 'squire, there is a clause in the post-office law to the effect that each post-master may be allowed two mills for delivering each newspaper not chargeable with postage, and Charles Clark takes the Bloomfield Gazette at my office which is not chargeable with pastage, and I thought as I was keeping store, you might say to Mr. Pierce's clerk to send a couple of coffee-mills!" I made the request, but have since learned that the coffe-mills never came to hand.

Marion Township in the north-west corner of the county, is just six miles square. It was first settled by David Wedmore, Obadiah Lowe, John J. Shelton, James Culbertson, Samuel T. and Benjamin Adams, Miller Shelton, Elisha B. Townsend and others. In 185\% the population of this township was 721 ; the value of hogs sold, $\$ 9,684$, and the value of cattle sold $\$ 7,144$. In 1863 her population was 861 ; her voters 162 ; her militia 126 , and her population between five and twenty-one, 391. She supports a fair share of schools, and religious matters are not entirely neglected, although it has been intimated that, in the ricinity of Albany, the only village in the township, moral culture has been somewhat neglected. By the way, I will just mention how they used to conduct political matters in this township. 
An Election.-In 1848, the whig and democratic parties of our county were well organized, and by the fall election the people were considerably stirred up on the subject of national politics. Marion township was, and still is thoroughly democratic, and at that time that party numbered not a few aspirants in that precinct. Hence the voters there were well disciplined. The election was held at the house of Mr. Samuel $\mathrm{T}$. Adams, and when the day arrived-all things having been previously arranged - the democracy of Marion assembled in the Soap Creek brush, formed into line on horseback and afoot, under the leadership of Obadiah Lowe, commander. Capt. Lowe was "right on the goose," and in order that his position might not be misunderstood, he placed himself " right on the record," by swinging about his neck a large ox-bell, and denominating himself the "bell-wether of old Marion," and attaching to the neck of his steed, as we are informed by one who was present, a gallon jug, filled with the best article of Black Hawk whisky, fresh from the worm! Thus armed and equipped as the law directs, the procession moved to the place of voting, where the contents of the jug afforded spirituous consolatian to the sovereigns, after which the people were addressed on the principal topics of the day, by John J. Shelton, (democrat) and Benj. Adams, (whig). At the conclusion of the speaking, three cheers went up for democracy, and Capt. Lowe's company marched to the polls in single file and deposited their ballots for Cass and Butler! It is needless to say that Capt. Lowe's company carried the day by an overwhelming majority in his township. Since that date there has been considerable change. Some of the citizens of Marion at the breaking out of the rebellion, went south and joined the rebel army. Mr. Lowe becoming disgusted with the people of the North, swapped his farm to a Missourian for a farm in Adair County, Mo., and moved South. Mr. B. Adams is now a pro-slavery democrat, while Mr. John J. Shelton is an abolitionist, but Marion township is still where it was, and still maintains her former standing as a sound democratic township. 
UnIox Township.-This township was first settled in the year 1840, along the Van Buren County line, near where Troy now is, by Fleming Mize, Samuel Evans, Samuel Swearengen, William McCormick, Joel Staley, B. F. Wilson, Tarlton Elder, Peter Marson, Levi Pickens, William D. Evans, and a few others. It was in this township that the first sermon was preached in our county. It was preached by Rev. Thomas Fitzpatrick of the Methodist Episcopal Church, at the house of Mr. McCormick, early in the year 1841. During the same year, Rev. L. W. Rankin organized a church in the same neighborhood, of New School Presbyterians. In 1842, Elder Post, a Baptist minister, organized in this township, the Fox River Church of that religious denomination. Mr. Post was a gentleman of liberal education, fair talents, a pleasant speaker, and considered a good man. He remained in the vicinity and preached for the people of this township for about three years. Union can boast of having built the first school house ever in our county. It was built in the spring of 1841 on the claim of Mr. Swearengen, of hewed logs, shingle roof, and was lathed and plastered.

Second MruL.-This township also had the second mill brilt in the county. It was a horse mill near the county line between this and Van Buren. It was built in April and May 1841, by Peter Marson and one Brunnelle, a Frenchman. In 1842 or 1843 they made a water mill of it, and ever since that time there has been some kind of a mill at that place. It was, and is a mere corn-cracker, and we have heard some very ludicrous stories told of it, one of which is, that it ground so very slow that after the miller threw the grain into the hopper in the morning, he would leave for a good portion of the day, starting the mill and setting it at the proper guage. In his absence, the story goes, the ground squirrels would come into the mill and take a position at the point of the shoe which fed the stones, and catch the corn as fast as it fell and before it entered the eye; when one got his jaw full he would return to his nest and another would "take his turn at the mill." 
So when the miller returned, the grist was generally gone and the mill clattering away, but comparatively no meal in the chest. Occasionally a crowd of squirrels around the eye, would cause some poor fellow to fall in, in which case he was bound to go through and come out, not exactly meal, but a dead squirrel, instead. After the discovery was made as to the thievish propensities of the squirrels, the miller was obliged to stay constantly at the mill to watch them off, and then frequently they would attack the bag's in the upper part of the mill, filled with corn and awaiting their turn, and cut holes in them and rob them of much of their contents. With all this precaution, it was not an unfrequent thing, when a sack of meal was taken home from this mill and opened to be sifted for mush or johnny-cake, to find the remains of a mashed squirrel or rat. We do not pretend to vouch for the truth of this, but so goes the story among the old settlers in that neighborhood.

In 1863 , this township contained a population of $1,097,193$ voters, 233 subject to military duty, and 595 between the ages of five and twenty-one years. It contains two villages Troy and Stringtown - and three post offices, Education and religion both were first iutroduced here in our county, and the inhabitants have not let either play in their hands, but at this time no township can rejoice in better schools or more correct morals than this.

First Orchard-Mr. Fleming Mize of this township, planted the first orchard that was in the county, and sowed the first wheat. He still lives on the same farm and now enjoys an abundance of the best fruit from the trees first put out in Davis. Mr. Mize is now on the shady side of life, but is still as active and vigorous as a youth of twenty-five. $\mathrm{He}$ is one of our best citizens, and notwithstanding his age, when there was a call for volunteers to defend our institutions and enforce the laws against the Southern rebellion, he placed himself in the ranks and was chosen a lieutenant of Company $\mathrm{D}$ in the $3 \mathrm{~d}$ Iowa Regiment of Cavalry. His health be- 
coming somewhat impaired, he resigned and returned to his home.

Perry Township was first settled by Samuel Mize, Wesley Young, Riley Macy, S. L. Saunders, C. Dilner, R. C. Miller, A. D. Williamson, G. S. Lockman, Samuel Evans, and others. Like the first settlers of other parts of our county, they labored under many disadvantages. There were no mills near, and all the grinding for this part of the country was done at the mills on the Des Moines, at Keosauqua, Bonaparte, \&c. At a very early day, a meeting-house was built in this township under the direction of the New School Presbyterian Church, which was called Shunam, and which was torn down but recently, and a more substantial building put up in its stead. At present Perry township has three organized churches, to-wit: The Christian, the Methodist Episcopal, and the New School Presbyterian - the last named owning Shunam meeting-house, which, however, is not closed against any religious denomination. This township also has six good school-honses, and five organized Sunday schools, which are well attended. Its population in 1856 was 715 , of which 127 were voters, and 110 subject to military duty. There were 124 heads of families, of whom 91 were owners of land. In that year the value of the hogs sold was $\$ 12,525$, and the value of cattle sold $\$ 7,069$. In 1863 the population was 738 , of which 136 were voters, and 105 subject to military duty. The number between the ages of five and twenty-one years, was 311. The township assessor has returned 1,018 neat cattle, valued at $\$ 7,929 ; 344$ horses, valued at $\$ 12,179 ; 30$ mules, worth $\$ 1,170 ; 183$ sheep, worth $\$ 2,346 ; 2,170$ hogs valued at $\$ 3,081$, and 120 velicles worth $\$ 3,104$. All this added to the value of other personal property and real estate amounts to a total valuation of $\$ 121,076$. I will here remark that the Shunam meeting house above named was the first house of worship built in the county. It was 20 by 32 feet, and was built principally by C. Dilner, Samuel Evans, and I. McMurry, assisted however, by C. E. Swift, and a few others. This township 
has neither a post office nor a village in it, but at one time started a town in opposition to the county seat, which will be noticed in another place. It is one of the finest townships for agricultural purposes in our county, contains an industrious, enterprising population, and has always sustained a high reputation for patriotism; always clinging to law, order, and good government.

Bloomfield Township, near the centre of the county, was first settled by Noble C. Barron, John W. Ellis, Col. S. S. Carpenter, Samuel Steele, Mathias D. Ham, Geo. W. Lester, Loyd A. and Ephraim M. Nelson, Dr. John J. Selman, Leroy C. and Charles Evans, Reason Wilkinson, Israel Kister, John Baldridge, William T. Johnson, Frank Street, and others. Noble C. Barron was the first settler at the place where Bloomfield now is - the original town plat occupying his claim. The settlements began in this township on the first of May, 1843, no person having settled here previous to that time, although many had been here selecting claims. About the time this township began to be settled, and before May 1843, several parties traced courses from Van Buren County into this, with a view of finding the center. Col. Carpenter, Judge Weaver and others made an effort and determined the center of the county to be near the present county seatabout two miles south-east of Bloomfield. Mr. A. D. Williamson, Clem Dillinger and others, also tried it, and located the center on the north side of Fox River, some two miles north-east of the present location. John W. Ellis, John W. Alley, Dr. Selman and others, formed another party, and about the 1st of April, 1843, with compass and chain, made a survey for the purpose of finding the center of the county, and determined in their own minds that the present location of our county town was the center of Davis County. Mr. Ellis and others, selected their claims, which they took possession of as soon as the Indians were removed, which took place some thirty days afterwards. The farm upon which $\mathrm{Mr}$. Ellis now resides, is the claim selected by him at that time. 
This party came to the house of William Goddard, this side of Troy, the first day. The next day they made a survey of about twelve miles, to this place, and from here they traveled to Quick's Grove (now owned by L. W. Bussey,) some four or five miles, and stayed over night. This, we presume, was the first party to suggest this place as the center of our county.

In 1849 the population of this township was 673 ; in $\mathbf{1 8 5 6}$ it was 1,619 , and in 1863 , exclusive of those in the army, 1,687. The number entitled to vote was 310 , and between the ages of five and twenty-one, 733. The returns of the assessor show 1,512 neat cattle of the value of $\$ 13,942 ; 610$ horses and mules, valued at $\$ 24,502 ; 1,910$ sheep, worth $\$ 4,374$, and 2,541 hogs, worth $\$ 3,389$. The value of lands is set down at $\$ 151,966$, and town lots at $\$ 43,545$. Moneys, credits and other personal property foot up $\$ 93,100$ - making the total value of all kinds of property in the township, $\$ 334,818$.

In the earlier days of this township, almost everything was turned to ridicule, - even the trials before justices' courts, no matter for what offense, nor how grave the charge, it was all the same to the settlers, and they generally took possession of the court or broke up the trial in a general row! In those days there was but little method and less order observed in such courts, and attorneys, witnesses, parties and bystanders nsually became more or less interested in the result of all trials or investigations. A case of hog stealing at an early day came before one of our justices, in which Powers Richey, W. J. Hawley and others, who did the pettifogging at that day, were engaged as attorneys. The defendant was charged with stealing a hog-a sandy sow, the property of one John Fitzpatrick, and upon said charge was duly arrested in the name of the United States of America, and brought before the court. The case was tried before L. C. Evans, at the house of Mr. Kister. It was a serious charge, and therefore one of those cases in which the whole community felt an interest. One of the first men of the neighborhood had been charged 
and arraigned for stealing a sandy sow! It was next in importance to a claim suit.

The preliminaries of the matter- "the sufficiency of the affidavit," and all such technicalities having been settled, the witnesses on the part of the United States of America, (among whom the aforesaid John Fitzpatrick and one L. N. English were most prominent,) came upon the stand, and made out the plainest case imaginable. Indeed they made too plain a case. We have been credibly informed that one witness swore that on passing by the claim of the accused that very day, he had examined his pigs, and that of thirteen he had marked them in twelve different marks.

This testimony had a powerful effect on the crowd. Some believed, while others disbelieved, and all became more or less excited and indignant-those on one side at the accusedthose on t'other at the witness. The "noise and confusion" having subsided, and all hands having liquored, the next witness was oalled and duly sworn, and testified that three or four days after the accused had butchered his hogs, witness had called upon him to make some inquiry and examination as to the missing sandy sow. Accused took witness to the bulk of salted pork, witness examined the heads, or rather pates of the hogs which he there found with the ears and snouts cut off, the eyes plucked out, and the head split open. In that condition witness recognized the identical head of his sandy sow-he knew the "countenance of the hog as soon as he laid his eyes on it!" At this stage of the proceedings all was in a bustle! Attorneys became excited-witnesses interested, and bystanders talked and shook their heads and began to make signs of uneasiness; meanwhile the court commanded the peace in the name of the old "Blue Back," and the reading of the riot act was called for.

It being now well in the afternoon, the ministerial officer of the court had got unusually "shot in the neck," and could not therefore preserve order, and I lany of those in attendance were well filled with spirits, so that loud talk began, and while 
many asserted their unbelief in the testimony, others said that the cutting the snouts and ears off, and plucking out the eyes, looked suspicious, while the principal witness stated that he never cut off the ears or snout, nor plucked the eyes out until the head was cooked and brought on the table! After some five or six speeches by Attorneys, the court came to the conclusion that "the defendant is not guilty as charged." This decision of the court was hailed by the friends of the accused with hideous yells and shouts, and to use the language of the justice, "the whole affair wound up with a d-d big spree!"

Some months afterwards the sandy sow was found in the possession of one Jeff. Sailing, who had won her at a game of poker from some of his neighbors who also had got her in the same way at a neighboring shooting-match. We never learned whether the sandy sow was returned to John or not, but the fact that she had thus turned up alive and well, fully vindicated the character of the accused squatter, while the witnesses on the part of the United States of America retired from the court without their customary share of the whisky.

Drakeville Township originally was part of the township of Bloomfield, and the settlers of the one were also the settlers of the other; but those who settled in what is now Drakeville township, were L. N. English, Linzy Trowbridge, Samuel Groat, Ezra M. Kirkham, Joseph Vials, John Fitzgerald, Joseph Hole, Mr. Fitzpatrick, and a few others. Mr. English was one of the justices of our county, and Dr. John D. Elbert, of Indian Prairie, Van Buren County, tells the following in connection with his appointment:

"A man by the name of English was among the first appointed magistrates by Gov. Chambers, and this was at the instance of $\nabla$ an Caldwell, an old and respectable citizen. Caldwell had a claim in dispute, and before he went to Burlington to have English appointed, took care to know how he stood on the claim question."

"Chambers swore he would not appoint him, beeause he was a drunkard, and that Caldwell must name same other 
man. Caldwell swore that there was but one other man in Davis qualitied, and that there might be a difficulty in that matter, for he had two wives. English was appointed, and Caldwell gained his land suit."

The population of this township in 1863 , was 655 , with 120 voters and 78 persons subject to military duty. Number between the ages of five and twenty-one, 285.

This township contains the village of Drakeville, and maintains a high reputation for morality, religion and patriotism. And although it is but six miles from the county seat, it does more business than any other village in the county.

Fox Township was first settled by Martin M. Jones, Joshua Patterson, Mark Noble, Conrad Scott, Leonard Eoff, William Crow, Jos. B. McCoy, Morris Gee, Wm. Wilkinson, Matthew Noble and others. But few, if any persons settled here before 1843 , but about that time the township began to fill up very rapidly with an enterprising population, and now contains some of the best farms in the county. I have been able to collect but few statistics of the township. The population in 1863 was 1,101 ; the number of dwelling-houses 297 ; number of voters 210 ; militia 145 ; number between the ages of five and twenty-one years, 506. The total valuation of personal and real property was $\$ 160,059$. This township contains two villages-West Grove and Mount Calvary-a schoolhouse in each district, and several meeting-houses. The largest wool-grower of the county resides in Fox, and some of our best orchards are also here.

Proxnmtr.- Some twelve or fifteen years ago, the Postmaster General established a Post Office in this township called "Lost Rock," and appointed Jos. W. Waldron, Postmaster. Being near Drakeville, and not very far from Bloomfield, this office paid nothing to the government, and accommodated but few people. The Postmaster-General determined, therefore, to discontinue it, and addressed a letter to the Postmaster something after this wise: 
Washington, D. C., July 18th, 1850.

"Sir-On account of your proximity to another office, this department has come to the conclusion to discontinue that of "Lost Rock." You will therefore deliver all books and papers belonging to your office, and all mail pouches, locks, keys and other property belonging to the United States to the Postmaster at Bloomfield, who will receipt to you for the same."

Very Respectfully your o'bt Serv't.,

"To P. M. at Lost Rock."

S. R. Новвге, 1st Ass't P. M. G.

Our worthy Postmaster received this communication, read it and shook his head. He read it again and again, but there was one word that puzzled him. He went to one of his neighbors for advice, who having been a justice of the peace for several years, and had learned the difference between a summons and an execution, was supposed to know a thing or two. But he too was at fault, and only shook his head gravely. They however, came to the sage conclusion that some one had been vilely traducing the Postmaster, and he was advised to write a letter to the department in self-vindication. In due time the Postmaster-General received an elaborately written document from the deeply injured functionary, giving a history of his ancestry and their worthy deeds. - Some of them had "font" in the revolution of course. He told of his long residence in our county, that he had been school director of his district and constable of Fox township for six years, and had given the best satisfaction; that he had been Postmaster once in Ohio and had never heard any complaint against him. In short, this was the first time he had ever been charged with Proximity - the guilt of which he indignantly denied! Upon his honor, he had never done such a thing in all his life! The effect the reading of our Postmaster's plea of innocence had upon the clerks of the department, is not certainly known, but it is supposed it was somewhat damaging to rest buttons. The ex-postmaster continued very despondent for some time, but receiving a letter from one of the clerks of the depart- 
ment informing him that "proximity" was not a charge affecting his moral character, he became reconciled.

It is eminently fit for us to say that at the breaking out of the rebellion, Mr. Waldron volunteered in defense of our country, and while in the line of his duty at the battle of Pittsburg Landing, lost his life while battling for the Union, the Constitution and the enforcement of the laws !

Pratrie Township, bordering on the Van Buren County line, was settled by Hugh Abernathy, Bushrod W. Craven, Jefferson Bryant, William Lawson, Benjamin W. Redman and others, as early as 1840 and ' 41 . The settlers along the eastern part of this township did not labor under so many disadvantages as those farther west, from the fact that Van Buren County was a part of the "Black-Hawk Purchase," and was; therefore, pretty well settled u by 1840 . The township contained a population in 1863 of 523 , of whom 97 were voters and 75 were subject to military duty. The number between the ages of five and twenty-one years was 137. The village of Pulaski is situated in this township, and will be noticed in another place. The township contains several religious organizations, several houses of public worship, and maintains her reputation for good schools and good morals. In early times, however, the people of this township, like most others in our county, did much of their work by neighborhood gatherings. For an account of one of these "Bees," I am indebted to Mr. Abernathy.

A Bes.-About twenty years ago, Mr. Jefferson Bryant, a squatter, had prepared a set of logs for a smoke house and stable, and invited his neighbors to come, on a certain day, and assist in raising, and also to cut and split some rails. Mrs. Bryant had some quilting to do, and all the neighbor women

- were invited to assist her in that business. The day was quite cool and somewhat unpleasant, but a great many people turned out. Indeed, several all the way from Keosauqua were at the chopping and raising. The labor in the woods was performed before dinner, and about noon the company 
repaired to the cabin, which was only twelve by fifteen feet. The number of women at the quilting made it impossible to set dinner in the house. This difficulty was soon obviated by making a log heap of Mr. Bryant's stable timbers, which being fired, was soon sufficient to roast an ox. Outside of the cabin near this burning heap, the table was spread, and a pioneer dinner served. Dinner being over, while the ladies cleared away the table, the men raised the smoke-house. Whisky was freely dispensed during the day, and by this time

\section{"They were red-hot with drinking, \\ So full of valor that they smote the air \\ For breathing in their faces,"}

and were ill at ease generally, and seemed to want something to amuse themselves. Without difficulty music was procured and the dance began. As many as could get in the cabin occupied it, and those outside occupied the space between the log-heap and the cabin. The weather became very cold during the night, so that a jug of whisky only lasted the company about three hours. The dance continued all night, and therefore several trips were made to the cabin of one William Lawson, that night. He kept wkisky for sale, and lived in a very open cabin,-it was neither chinked nor daubed-and on account of the unusual demand for spirits, he had been forced to add water to make it hold out. And it is said he kept an iron rod in the fire all night, so as to have it hot when the jug came, to thaw the liquor so that it would run out of the barrel !

We have heard a great many stories of whisky freezing in this part of the country, but this case we cannot dispute, as we have it from the lips of Mr. Abernathy, who was present, that when the jug arrived at Mr. Bryant's, the liquor was mush ice! During this night's exercises, one Samuel Turner became rather limber-jointed to remain on his pedal extremities, and remained much under foot for a while. In order to place him out of the way, and to make him more comfortable than he seemed to be in the midst of so gay an assembly, he 4 
was placed in the loft of the cabin. The joists of the cabin were small poles overlaid with clapboards. At the end next the sod chimney the joist was, about one foot from the wall, but the boards extended over it. Mr. Turner's bed was rather too hard for him to remain on one side long at a time, and he rolled over from side to side until he finally got too near the end of the building, the boards tipped up, and the unfortunate squatter was picked up in a blazing cabin fire, sonsiderably worse for his fall. The loss of his hair, eye-brows, \&c., constituted the principal damage he sustained, while his nnexpected tumble caused the ladies some fright, and furnished the gentlemen something to laugh and joke about. When flakey darkness began to break in the east, and the "grey lines began to fret the clouds," our party dispersed; like unbridled colts

$$
\begin{aligned}
& \text { "- they take their courses } \\
& \text { East, West, North, South; } \\
& \text { Or, like a school broke up, } \\
& \text { Each hurries towards his home," }
\end{aligned}
$$

well pleased, and happier far than aught else could have rendered him at that time.

\section{HISTORY OF IOWA TROOPS.}

We anticipate great pleasure in the perusal of Mr. L. D. Ingersoll's forthcoming history of the part borne by the troops from this State in the recent conflict. The author, under the nom de guerre of "Linkensale," was well known throughout Iowa, before the war, as a ready, original and very entertaining political writer.

The battle of Wilson's Creek had no more than been fought when Ingersoll began to give practical form to the idea of writing a full and impartial history of every Iowa regiment, and to this end he visited in the field every body of troops from the State that was at all accessible-gleaning such information from the officers and men themselves as was necessary to a minute and truthful account of their gallant actions. The work cannot but be interesting to every citizen of Iowa. 
Copyright of Annals of Iowa is the property of State of Iowa, by \& through the State Historical Society of Iowa and its content may not be copied or emailed to multiple sites or posted to a listserv without the copyright holder's express written permission. However, users may print, download, or email articles for individual use. 